\title{
Rare Case of Conjoined Twins: Pictorial Essay
}

\section{Sakhi $\mathbf{P}^{1}$, Taori $\mathrm{A}^{\mathbf{1}}$, Patel $\mathbf{K}^{1}$, Singh $\mathbf{S}^{2}$}

${ }^{1}$ Department of Radiodiagnosis, ${ }^{2}$ Department of Pediatric Surgery, SAIMS, Indore

\begin{abstract}
Conjoint twins are rare, presenting a unique challenge to radiologist and pediatric surgeons. For surgical separations, accurate preoperative imaging is necessary for operative planning prognostic information as well as important for patient counseling. There are different types of anatomical connections. MRI and CT scan give excellent anatomical and bony details like organ position, shared organs and vascular anatomy. We present a pictorial essay on a previously unreported variation of pygopagus twins.
\end{abstract}

Keywords: Conjoint Twins, Pygopagus

\section{Introduction}

Conjoined twins are rare, but the exact prevalence is unknown. The estimated prevalence in the literature varies widely, from $1: 50,000$ to $1: 200,000 .^{1,2,3,4}$ An increased prevalence is observed in parts of Southeast Asia and Africa, with reported occurrence ranging from 1:14,000 to $1: 25,000 .{ }^{5}$ There is a female predominance on the order of $3: 1{ }^{4}$ The twins are monozygotic; mono amniotic mono chorionic; there is failure of separation of the embryonic plate between 13 and 17 days of gestation. ${ }^{3,6,7,8}$ Conjoined twins are classified according to the most prominent site of

Correspondence to: Dr. Pramod Sakhi, Department of Radio Diagnosis, Sri Aurobindo Institute of Medical Sciences and P.G. Institute, Indore.

Email: drpramod109@yahoo.co.in connection (Table.1): the thorax [thoracopagus], abdomen [omphalopagus], sacrum [pygopagus], pelvis [ischiopagus], skull [craniopagus], face [cephalopagus], or back [rachipagus].

\begin{tabular}{|l|l|l|}
\hline Twin Type & $\begin{array}{l}\text { Conjoined } \\
\text { Area }\end{array}$ & $\begin{array}{l}\text { Percentage } \\
\text { of cases }\end{array}$ \\
\hline Thoracopagus & Thorax & 40 \\
\hline Omphalopagus & Abdomen & 33 \\
\hline Pygopagus & $\begin{array}{l}\text { Sacrum or } \\
\text { buttocks }\end{array}$ & 19 \\
\hline Ischiopagus & Pelvis & 6 \\
\hline Craniopagus & Cranium & 2 \\
\hline Parapagus & $\begin{array}{l}\text { Ventro } \\
\text { lateral Area }\end{array}$ & - \\
\hline
\end{tabular}

\section{Imaging Importance}

Conjoined twins present unique challenge to radiologists, obstetrician and pediatric surgeons. Planning of surgery is aided by accurate preoperative imaging. The area of 


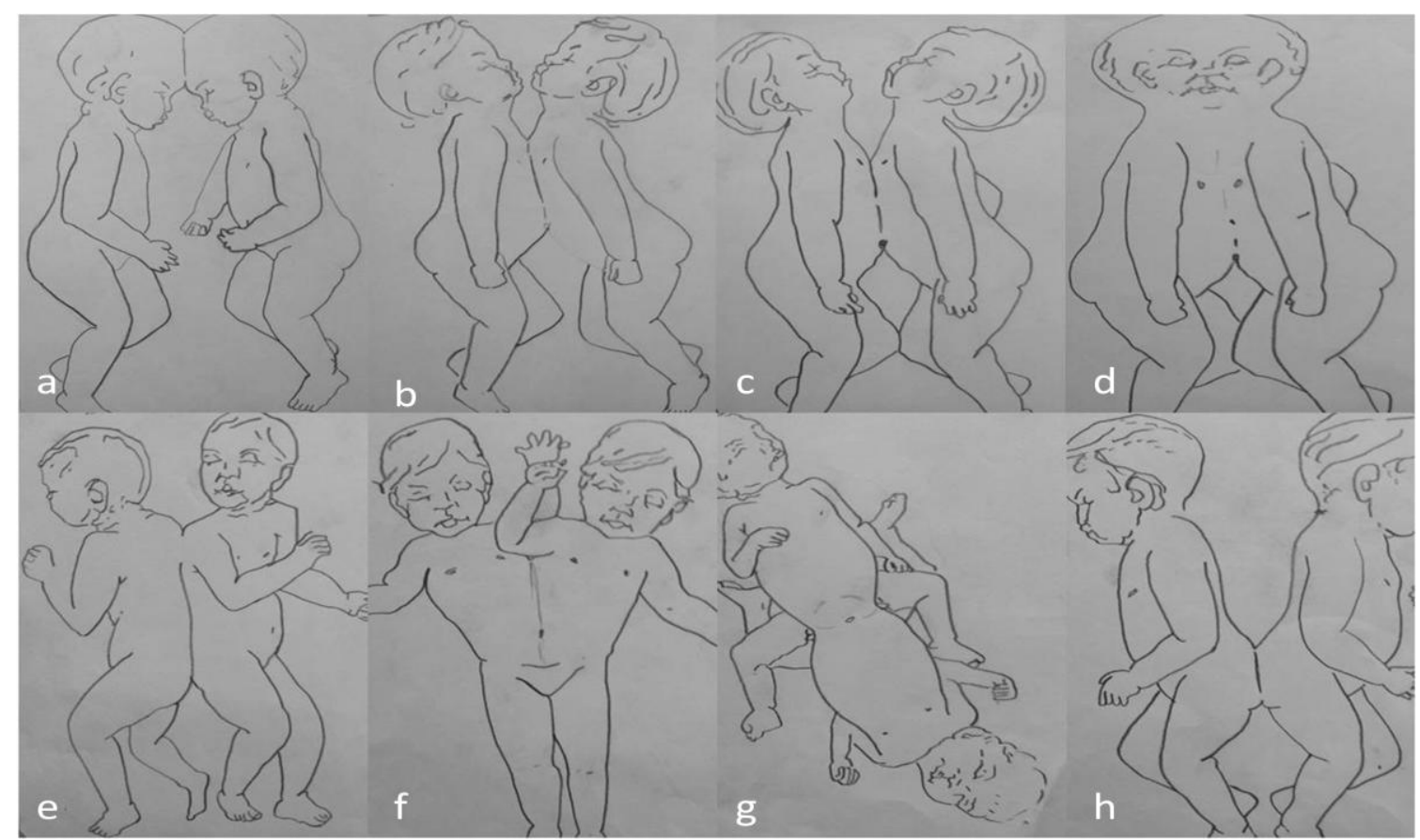

Fig.1: a.Craniophagus b.Thoracopagus c.Omphalopagus d.Cephalopagus e.Rachipagus f.Parapagus g.Ishiopagus h.Pygopagus ${ }^{9}$



Fig. 2: Both Male babies of 2 month with fusion at lumbosacral region with separate GU System and Anus. On Skiagram there is fusion of babies at lumbo sacral region with non visualization of sacrum in baby on left. fusion largely determines the imaging modality used. Each set of conjoined twins is unique, an imaging strategy to accurately define anatomic fusion, vascular anomalies and other associated abnormalities is important for surgical planning and prognostic information.

\section{Pygopagus [usual presentation]}

Pygopagus twins are joined dorsally, facing away from each other and sharing the sacrococcygeal and perineal regions. Fusion of sacral vertebrae frequently occurs, but the spinal cords usually remain separate. Usually, there is a single anus with one or two rectums, the remainder of the intestine being separate. Twins may share a genitourinary system with a single bladder and urethra. The upper bodies are not fused, and there are four arms and four legs. ${ }^{2,9,13,14}$ 


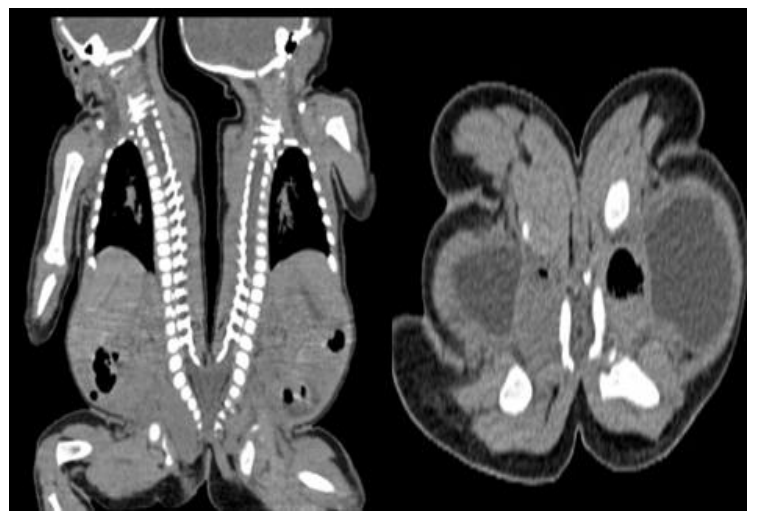

Fig. 4: On CT scan (Sag and axial) Spina bifida from $L 4$ vertebra downwards with fusion of filum terminale.

\section{In our case}

We present a variant of Pygopagus conjoined male twin, where the only area of fusion was filum terminale without any bony, vascular genitourinary or other anatomic fusion. This is probably the: "First case of Pygopagus twins to present in such a manner." Hence we highlight its imaging features on conventional radiography/CT/MRI as well as surgery. After taking clinical detail and morphology of conjoint twin, patient was subjected to digital radiography, then $\mathrm{CT}$ on Siemen definition- As 64 Slice MD CT scanner and 1.5T MRI Symphony TIM 18 channel MRI scanner.

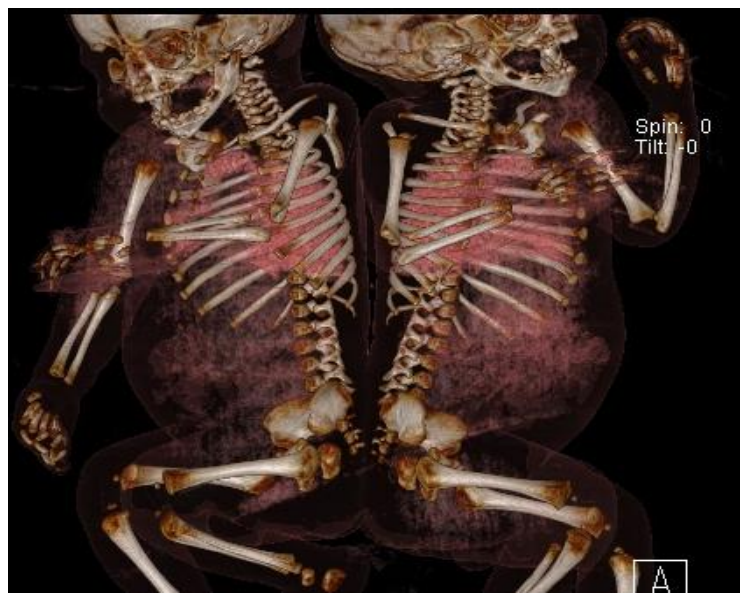

Fig.5: 3D rendering of the conjoined twins.

\section{Discussion}

This pygopagus baby was delivered via cesarean section outside our institute and then referred for further management. These conjoint twins were evaluated at 2 months of age. During the preoperative planning, two separate surgical teams were established, each with responsibility for one of the twins; an experienced pediatric surgeon took charge for overall coordination. We had 2 pediatric surgeons, 2 neuro surgeons and 2 anesthetist in our team. Surgery was done successfully without complication as the surgical prognosis of this twin was better, where organs were not shared between twins like in usual presentation of pygopagus and omphalopagus twins described by Sanders $\mathrm{RC}$ et al. ${ }^{12}$

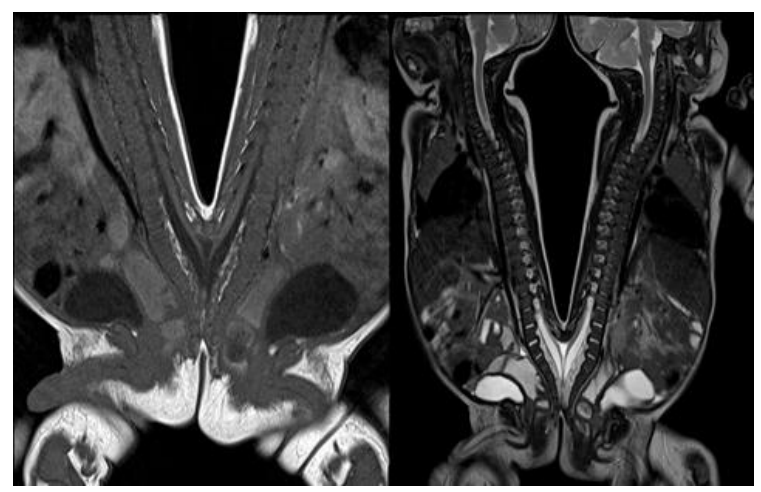

Fig.6: On T1 Sag \& T2 Sag WI: Both the cords are low lying and tethered and are seen lying approximately at L5-S1 level, thereafter the filum terminale are seen fused together at approx. S2-S3 level in single thecal sac.

Preoperative imaging of conjoined twins and their interpretation presents and poses a big challenge to a radiologist. Their separation is also very challenging for the pediatric surgeons hence an imaging strategy to accurately define anatomic fusion, vascular anomalies, and associated abnormalities are important for proper surgical planning and prognostication. 




Fig.7: T2 Axial WI: Two Separate Cord Seen at upper lumbosacral region; Thereafter the filum terminale are seen fused together at approx. S2-S3 level in single thecal sac.

With accurate preoperative imaging, rate of successful separation of conjoined twins has improved. The site of conjunction largely determines the imaging modalities used. MR imaging provides excellent overall anatomic demonstration, and visceral conjunction. Organ position is best assessed with this multiplanar technique. CT also provides good anatomic detail; CT which when performed with standard bone algorithms and in addition to three-dimensional reconstruction helps in excellent evaluation of bony fusion abnormalities and defects, and thus MR imaging and CT can be used together in conjunction to guide other imaging investigations.

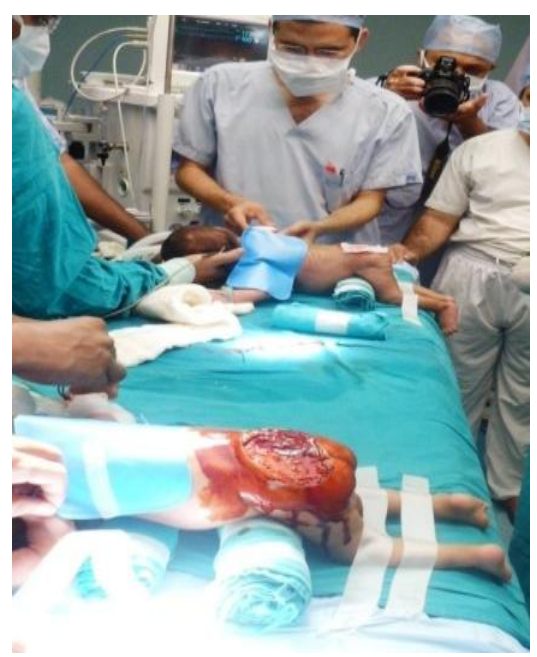

Fig. 8: Post Operative: Babies Successfully Separated

\section{Conclusion}

Certain imaging modalities and investigations are desirable in evaluating conjoined twins and can be determined according to the primary site of conjunction which highly varies. Thus even though each set of twins is unique; certain broad based generalizations can be made, but still exact imaging performed must be tailored to the twins involved and the requirements of the pediatric surgeons for conducting their separation.

\section{References}

1. Hanson JW. Incidence of conjoined twinning. Lancet 1975; 2:1257.

2. Spitz L. Conjoined twins. Br J Surg 1996; 83: 1028-1030.

3. Barth RA, Filly RA, Goldberg JD, Moore P, Silverman NH. Conjoined twins: prenatal diagnosis and assessment of associated malformations. Radiology 1990; 177:201-207.

4. Edmonds LD, Layde PM. Conjoined twins in the United States, 1970-1977. Teratology 1982; 25: 301-308. 
5. Diaz JH, Furman EB. Perioperative management of conjoined twins. Anesthesiology 1987; 67:965-973.

6. Zimmermann AA. Embryological and anatomic considerations of conjoined twins. Birth Defects 1967; 3:18-27.

7. Jones KL. Smith's recognizable patterns of human malformation. 2nd ed. Philadelphia, Pa: Saunders,1988; 594 595.

8. Rudolph AJ, Michaels JP, Nichols BL. Obstetric management of conjoined twins. Birth Defects 1967; 3:28-37.

9. Spencer R. Anatomic description of conjoined twins: a plea for standardized terminology. J Pediatr Surg 1996; 31:941-944

10. La Torre R, Fusaro P, Anceschi MM, Montanino-Oliva M, Modesto S, Cosmi EV. Unusual case of caudal duplication [dipygus]. J Clin Ultrasound. 1998 MarApr;26[3]:163-5.

11. Melikoglu M, Aslan A, Mete A, Ozkaynak C, Inan M, Karaveli S. A case of thoraco-omphalo-ischiopagus bipus conjoined twins. J Pediatr Surg 1997; 32:656-658.

12. Conjoined twins. In: Sanders RC, ed. Structural fetal abnormalities: the total picture. St Louis, Mo: Mosby, 1996; 223-227.

13. Fitzgerald EJ, Toi A, Cochlin DL. Conjoined twins: antenatal ultrasound diagnosis and a review of the literature. Br J Radiol 1985; 58:1053-1056.
14. O’Neill JA, Holcomb GW, Schnaufer L, et al. Surgical experience with thirteen conjoined twins. Ann Surg 1988; 208:299-312. 